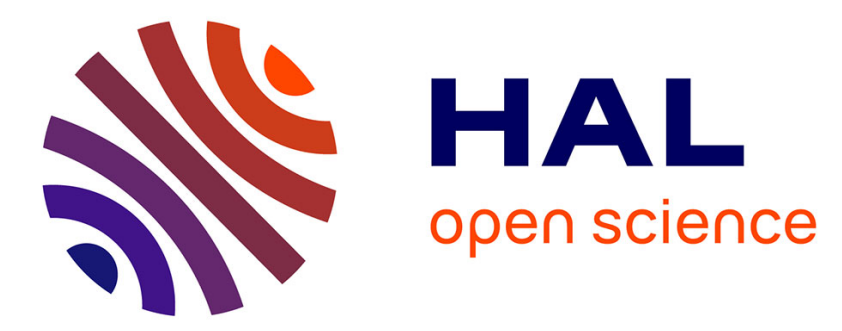

\title{
Optimization of the composition of perovskite type materials for further elaboration of four-way catalysts for gasoline engine
}

\author{
J. Wu, J P Dacquin, C. Cordier, C. Dujardin, Pascal Granger
}

\section{To cite this version:}

J. Wu, J P Dacquin, C. Cordier, C. Dujardin, Pascal Granger. Optimization of the composition of perovskite type materials for further elaboration of four-way catalysts for gasoline engine. CAPoC11, Oct 2018, Brussel, Belgium. hal-02338833

\section{HAL Id: hal-02338833 \\ https://hal.science/hal-02338833}

Submitted on 30 Oct 2019

HAL is a multi-disciplinary open access archive for the deposit and dissemination of scientific research documents, whether they are published or not. The documents may come from teaching and research institutions in France or abroad, or from public or private research centers.
L'archive ouverte pluridisciplinaire HAL, est destinée au dépôt et à la diffusion de documents scientifiques de niveau recherche, publiés ou non, émanant des établissements d'enseignement et de recherche français ou étrangers, des laboratoires publics ou privés. 
Submitted to the journal Topics in Catalysis within the CAPoC11 held in Brussel october $29^{\text {th }}$ $31^{\text {th }}, 2018$

\title{
Optimization of the composition of perovskite type materials for further elaboration of four-way catalysts for gasoline engine
}

\author{
J. Wu ${ }^{1}$, J.P. Dacquin ${ }^{1}$, C. Cordier ${ }^{2}$, C. Dujardin ${ }^{1}$, P. Granger ${ }^{1} *$ \\ ${ }^{1}$ Univ. Lille, CNRS, Centrale Lille, ENSCL, Univ. Artois, UMR 8181 - UCCS - Unité de Catalyse et \\ Chimie du Solide, F-59000 Lille, France \\ ${ }^{2}$ Univ. Lille - UMR8207 -Unité Matériaux Et Transformations, F-59000 Lille, France
}

* Corresponding author : pascal.granger@univ-lille.fr

\begin{abstract}
This study compares the impact of A and B-substitution in parent stoichiometric and Ladeficient $\mathrm{LaFeO}_{3}$ perovskite for subsequent development as suitable substrate in Three-Way Catalysis. $\mathrm{CO}$ and propene oxidation were investigated to probe their oxidative behavior. It was found that the activity cannot be related neither to the specific surface area nor to the nature of oxidic iron species but more likely to intra and extra lattice of copper species as well as related defective sites.
\end{abstract}

\section{Key words}

PGM-free TWC, Perovskite, CO oxidation, propene oxidation, La-deficient perovskite 


\section{Introduction}

Nowadays Three-Way-Catalysts (TWC) are considered as a mature technology suitable for the simultaneous abatement of $\mathrm{NO}_{\mathrm{x}}, \mathrm{CO}$ and unburnt hydrocarbons. The use of precious metals and rare earths, as oxygen storage materials, is requested in significant amount to get the highest efficiency near stoichiometric conditions. More stringent standard regulations have recently arisen which account for small suspended particle emissions from gasoline engines keeping the other atmospheric pollutants at their lowest limit. Accordingly, improved technologies are expected combining particulate filter and TWC [1]. In a first approach, a particulate filter could be coated by materials currently used in three-way catalysis in a simple way taking into account a higher thermal stability than usual TWC technology. In practice, perovskite-based catalysts could be an attractive alternative as earlier demonstrated by Nishihata et al. [2] who found that nano-sized precious metal particles would be protected from thermal sintering when interacting with the perovskite. The concept of self-regenerative behavior was further debated in different environmental applications showing significant redispersion processes of precious metals at the surface according to appropriate ex situ redox thermal treatments [3-6]. Perovskites are also well-recognized for their oxidative properties and widely studied for soot combustion [7,8]. As a matter of fact, the redox properties of those varieties of mixed oxides can be carefully optimized by adjusting the extent of substitution in $\mathrm{A}$-site and $\mathrm{B}$-site of $\mathrm{ABO}_{3}$ perovskite structures. Theoretical calculations predicted that the structural stability of A-site deficient cubic phase is enhanced compared to stoichiometric counterparts [9]. It was found that La-deficient materials can considerably enhance oxidation reactions and the thermal stability of those materials [10,11]. In addition, computational calculations also led to the conclusion that calcium doping can enhance oxygen conductivity in $\mathrm{LaFeO}_{3}$ [12].

Since the discovery of Nishihata et al. [2] the debate on the use of perovskite in Three-way catalysis is still open leading to controversial statements especially if PGM-free perovskite can be reasonably envisioned for such application $[13,14]$. Obviously, the gap is significant because up to now most of the attempts revealed relatively low selective NO conversion to nitrogen in stoichiometric conditions. Nevertheless, the continuous evolution of the normative context, becoming more and more stringent, and taking into account the urgent need to reduce the use of critical materials of strategic importance such as Platinum Group Metals and rare earths, make that perovskite materials are always of practical interest. Parent $\mathrm{LaFeO}_{3}$ perovskite has been considered in this study with the aim to optimize La-deficiency and 
subsequent substitutions of $\mathrm{La}$ by $\mathrm{Ca}$ and $\mathrm{Fe}$ by $\mathrm{Cu}$ in order to promote Oxygen Storage Capacity (OSC) and fulfill specific requirements in terms of reduction of rare earth content. Particular attention was paid to the oxidative properties of the synthesized perovskites.

\section{Experimental}

\subsection{Preparation and physicochemical characterization of perovskite based catalysts}

Perovskites were prepared according to a conventional citric method earlier described [4]. The structure was obtained after calcination in air at $600^{\circ} \mathrm{C}$ overnight. The structural properties of freshly-prepared samples were characterized by XRD analysis performed on a Bruker AXS D8 Advance diffractometer in Bragg-Brentano geometry using $\mathrm{Cu} K \alpha$ radiation $(\lambda=0.154$ nm, 40 kV, 30 mA). Ex situ Mössbauer spectroscopic data were obtained at room temperature using a ${ }^{57} \mathrm{Co}(\mathrm{Rh})$ source. Data fitting was performed with Lorentzian shape peaks and hyperfine parameters (hyperfine field (HF), isomer shift (IS), quadrupole splitting (QS)) were calculated with metallic iron as reference. $\mathrm{H}_{2}$-Temperature-Programmed Reduction $\left(\mathrm{H}_{2}-\mathrm{TPR}\right)$ experiments were performed on a Micromeritics Autochem II 2920 analyzer. BET surface were calculated from $\mathrm{N}_{2}$ physisorption measurements at $-196^{\circ} \mathrm{C}$ on a Micrometric Flowsorb III. XPS analysis was carried out on an AXIS Ultra DLD Kratos spectrometer fitted with a monochromatized aluminium source. Binding Energy (B.E.) values were referenced to the C1s B.E. at $285 \mathrm{eV}$.

\subsection{Catalytic measurements}

Catalytic measurements were carried out in a fixed bed flow reactor on $200 \mathrm{mg}$ of catalysts in powder form (average grain size of $150 \mu \mathrm{m}$ ) mixed with silicon carbide. Catalytic performances were evaluated from successive Temperature-Programmed Reaction (TPR), in the temperature range $100-550^{\circ} \mathrm{C}$, according to the methodology described in Fig. 1 (Stoichiometry (STO1)/lean/rich/stoichiometry (STO2)). The total flow rate, adjusted to 12 $\mathrm{Lh}^{-1}$, corresponded to a Gas Hourly Space Velocity of $60,000 \mathrm{mLh}^{-1} \mathrm{~g}^{-1}$ with inlet composition reported in Table 1. The composition of the outlet gas composition was monitored by a Thermo Scientific Model 42i-HL chemiluminescence analyzer for $\mathrm{NO}_{\mathrm{x}}$ and an Agilent Technologies 490 micro GC for the detection and the quantification of $\mathrm{N}_{2}, \mathrm{~N}_{2} \mathrm{O}, \mathrm{CO}$, propane, propene and $\mathrm{CO}_{2}$. 


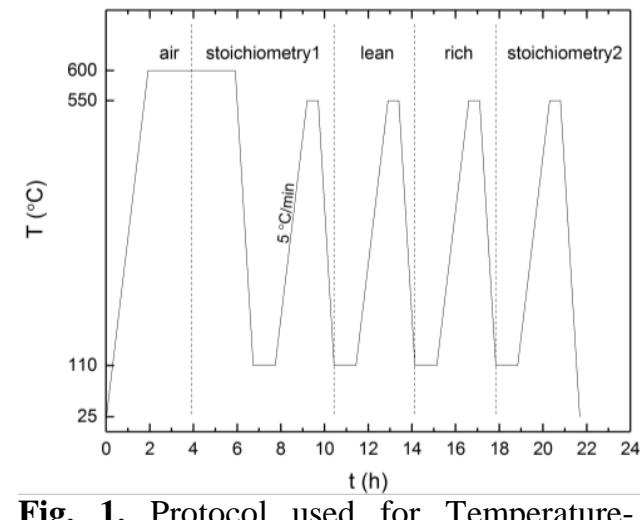

Fig. 1. Protocol used for TemperatureProgrammed Reaction experiments.

Table 1. Composition of the gas mixture during TPR experiments

\begin{tabular}{cccccccccc}
$\begin{array}{c}\text { Gas } \\
\text { (vol.\%) }\end{array}$ & $\mathrm{NO}$ & $\mathrm{CO}$ & $\mathrm{C}_{3} \mathrm{H}_{6}$ & $\mathrm{C}_{3} \mathrm{H}_{8}$ & $\mathrm{H}_{2}$ & $\mathrm{O}_{2}$ & $\mathrm{CO}_{2}$ & $\mathrm{H}_{2} \mathrm{O}$ & $\mathrm{He}$ \\
\hline Lean & 0.1 & 0.5 & 0.03 & 0.015 & 0.17 & 0.90 & 15 & 10 & balance \\
Stoichio & 0.1 & 0.7 & 0.045 & 0.022 & 0.23 & 0.73 & 15 & 10 & balance \\
Rich & 0.1 & 0.9 & 0.06 & 0.03 & 0.3 & 0.55 & 15 & 10 & balance
\end{tabular}

\section{Results and Discussion}

\subsection{Bulk properties of stoichiometric and non stoichiometric substituted perovskites}

XRD patterns recorded on parent $\mathrm{LaFeO}_{3}$ and $\mathrm{La}_{0.7} \mathrm{FeO}_{3}$ substituted by calcium and copper are reported in Fig. 2. The appearance of intense X-ray diffraction peaks at $2 \theta=32.19^{\circ}$, $39.67^{\circ}, 46.14^{\circ}$ and $57.40^{\circ}$, corresponding to the typical (121), (220), (202) and (240) reflection plans, characterizes the orthorhombic crystal structure with a space group Pbnm (JCPDS PDF 37-1493). Let us note that the weak reflections at $2 \theta=35.6^{\circ}$ and $38.7^{\circ}$ underline a small segregation of cubic $\mathrm{CuO}$ phase with characteristic (-111) and (111) reflections. The structural parameters and the volume of the cell unit have been calculated from the Rietveld refinement method (see Table 2). A significant lattice contraction is discernible after substitution of lanthanum by calcium which accentuates on the stoichiometric composition $\mathrm{La}_{0.6} \mathrm{Ca}_{0.4} \mathrm{Fe}_{0.8} \mathrm{Cu}_{0.2} \mathrm{O}_{3}$ as previously observed [15]. Such changes cannot be reasonably explained by the substitution of $\mathrm{La}^{3+}$ by $\mathrm{Ca}^{2+}$ having a comparable ionic radius, i.e. $1.36 \AA$ vs. $1.34 \AA$ respectively. On the other hand, the stabilization of iron in unusual oxidation state $\mathrm{Fe}^{4+}$ $(0.585 \AA)$ instead of $\mathrm{Fe}^{3+}(0.685 \AA)$, for preserving the electroneutrality of this system, could explain such contraction effects.

Table 2. Structural and textural properties of $\mathrm{Ca}$ and $\mathrm{Cu}$ substituted stoichiometric and Ladeficient perovskite materials

\begin{tabular}{lccccccc}
\hline Catalyst & $a(\AA)$ & $b(\AA)$ & $c(\AA)$ & Unit cell vol. $\left(\AA^{3}\right)$ & $\begin{array}{c}\text { Cryst. } \\
\text { Size }(\mathrm{nm})\end{array}$ & $\begin{array}{c}\text { SSA } \\
\left(\mathrm{m}^{2} \cdot \mathrm{g}^{-1}\right)\end{array}$ & $\begin{array}{c}\mathrm{Fe}^{4+} \\
(\%)\end{array}$ \\
\hline $\mathrm{LaFeO}_{3}$ & $5.560(1)$ & $7.861(0)$ & $5.557(1)$ & $242.88 \pm 0.05$ & 29.4 & 15.5 & 4.8 \\
$\mathrm{La}_{0.7} \mathrm{FeO}_{3}$ & $5.560(0)$ & $7.878(1)$ & $5.535(1)$ & $242.44 \pm 0.03$ & 21.7 & 35.5 & - \\
$\mathrm{La}_{0.7} \mathrm{Fe}_{0.8} \mathrm{Cu}_{0.2} \mathrm{O}_{3}$ & $5.545(1)$ & $7.857(1)$ & $5.550(1)$ & $241.80 \pm 0.05$ & 28.6 & 23.2 & - \\
$\mathrm{La}_{0.6} \mathrm{Ca}_{0.1} \mathrm{Fe}_{0.8} \mathrm{Cu}_{0.2} \mathrm{O}_{3}$ & $5.544(1)$ & $7.837(1)$ & $5.539(0)$ & $240.66 \pm 0.03$ & 32.5 & 22.1 & - \\
$\mathrm{La}_{0.6} \mathrm{Ca}_{0.2} \mathrm{Fe}_{0.8} \mathrm{Cu}_{0.2} \mathrm{O}_{3}$ & $5.542(0)$ & $7.785(0)$ & $5.531(0)$ & $238.63 \pm 0.03$ & 30.4 & 21.3 & - \\
$\mathrm{La}_{0.6} \mathrm{Ca}_{0.4} \mathrm{Fe}_{0.8} \mathrm{Cu}_{0.2} \mathrm{O}_{3}$ & $5.525(0)$ & $7.810(0)$ & $5.436(1)$ & $234.56 \pm 0.06$ & 24.4 & 32.4 & 17.3 \\
\hline
\end{tabular}



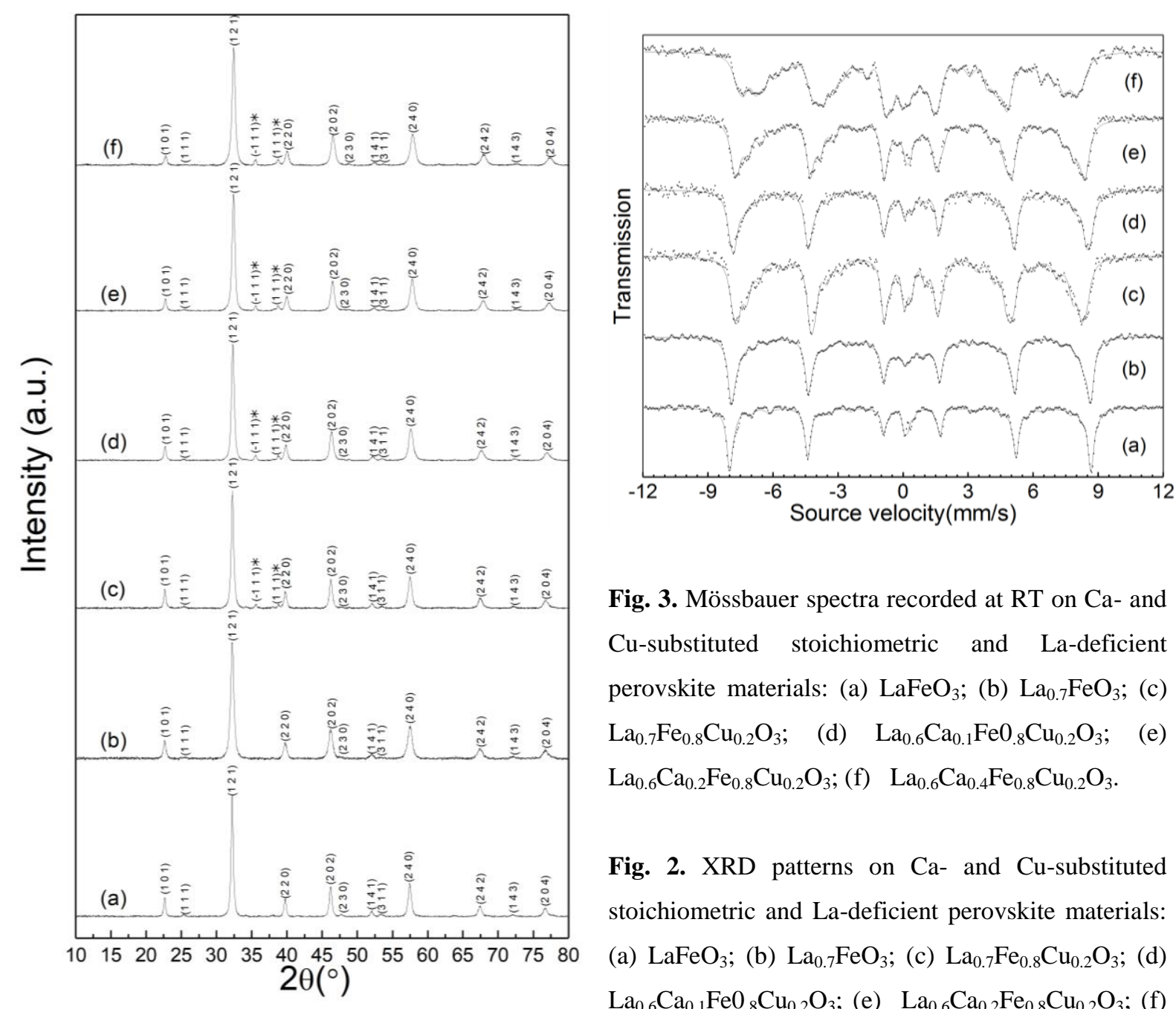

Fig. 3. Mössbauer spectra recorded at $\mathrm{RT}$ on $\mathrm{Ca}-$ and $\mathrm{Cu}$-substituted stoichiometric and La-deficient perovskite materials: (a) $\mathrm{LaFeO}_{3}$; (b) $\mathrm{La}_{0.7} \mathrm{FeO}_{3}$; (c) $\mathrm{La}_{0.7} \mathrm{Fe}_{0.8} \mathrm{Cu}_{0.2} \mathrm{O}_{3} ; \quad$ (d) $\mathrm{La}_{0.6} \mathrm{Ca}_{0.1} \mathrm{Fe}{ }_{.8} \mathrm{Cu}_{0.2} \mathrm{O}_{3}$; $\mathrm{La}_{0.6} \mathrm{Ca}_{0.2} \mathrm{Fe}_{0.8} \mathrm{Cu}_{0.2} \mathrm{O}_{3}$; (f) $\mathrm{La}_{0.6} \mathrm{Ca}_{0.4} \mathrm{Fe}_{0.8} \mathrm{Cu}_{0.2} \mathrm{O}_{3}$.

Fig. 2. XRD patterns on $\mathrm{Ca}$ - and $\mathrm{Cu}$-substituted stoichiometric and La-deficient perovskite materials: (a) $\mathrm{LaFeO}_{3}$; (b) $\mathrm{La}_{0.7} \mathrm{FeO}_{3}$; (c) $\mathrm{La}_{0.7} \mathrm{Fe}_{0.8} \mathrm{Cu}_{0.2} \mathrm{O}_{3}$; (d) $\mathrm{La}_{0.6} \mathrm{Ca}_{0.1} \mathrm{Fe}_{.8} \mathrm{Cu}_{0.2} \mathrm{O}_{3}$; (e) $\mathrm{La}_{0.6} \mathrm{Ca}_{0.2} \mathrm{Fe}_{0.8} \mathrm{Cu}_{0.2} \mathrm{O}_{3}$; (f) $\mathrm{La}_{0.6} \mathrm{Ca}_{0.4} \mathrm{Fe}_{0.8} \mathrm{Cu}_{0.2} \mathrm{O}_{3}-(*) \mathrm{CuO}$ phase.

The Mössbauer spectroscopy is a powerful technique to probe the oxidation state of iron stabilized in different coordination sites. As exemplified in Fig. 3(a), spectra recorded on the parent material at room temperature (RT) essentially reveals sextet environments of $\mathrm{LaFeO}_{3}$. However, significant broadening is noticeable on partially substituted samples which accentuates on the stoichiometric $\mathrm{La}_{0.6} \mathrm{Ca}_{0.4} \mathrm{Fe}_{0.8} \mathrm{Cu}_{0.2} \mathrm{O}_{3}$ perovskite (spectrum Fig. 3(f)). Several contributions were included in spectrum fitting associated to different isomer shifts and Quadrupole Splitting which allow the identification of various coordination sites for $\mathrm{Fe}^{3+}$. The main observation of a sextet on $\mathrm{LaFeO}_{3}$ and $\mathrm{La}_{0.7} \mathrm{FeO}_{3}$, (figures 3 (a-b), corresponds to $\mathrm{Fe}^{3+}$ ions in the octahedron's center surrounded by six $\mathrm{O}^{2-}$ ions on $\left(\begin{array}{lll}0 & 0 & 1\end{array}\right),\left(\begin{array}{lll}1 & 0 & 0\end{array}\right)$ and $\left(\begin{array}{lll}0 & 1 & 0\end{array}\right)$ faces (IS $=0.29-0.57 \mathrm{~mm} / \mathrm{s}$ ) on whereas $\mathrm{La}^{3+}$ ions occupy eight corners of the orthorhombic unit cell $\left(\mathrm{a} \approx \mathrm{b}<\mathrm{c}\right.$ and $\alpha=\beta=\gamma=90^{\circ}$ ). However, the formation of $\mathrm{Fe}^{3+}$ in distorted octahedral and tetrahedral centers (IS $=0.13-0.49 \mathrm{~mm} / \mathrm{s}$ ) as well as the characterization on 
$\mathrm{Fe}^{4+}$ (IS $=0.07-0.15 \mathrm{~mm} / \mathrm{s}$ ) is observed especially for stoichiometric composition. These observations seems to agree with Pecchi et al. [15] who demonstrated that increasing the calcium substitution favors the stabilization of $\mathrm{Fe}^{4+}$ species. On the other hand the lack of detection of $\mathrm{Fe}^{4+}$ on La-deficient samples could suggest that the neutralization could likely involve the formation of anionic vacancies. Less structural disorder seems to occur on Ladeficient perovskites compared to $\mathrm{La}_{0.6} \mathrm{Ca}_{0.4} \mathrm{Fe}_{0.8} \mathrm{Cu}_{0.2} \mathrm{O}_{3}$ which in a certain way could reflect a greater structural stability as reported elsewhere $[10,11]$.

\subsection{Bulk reducibility}

The reducibility of $\mathrm{La}_{1-\mathrm{y}} \mathrm{Ca}_{\mathrm{y}} \mathrm{Fe}_{1-\mathrm{x}} \mathrm{Cu}_{\mathrm{x}} \mathrm{O}_{3}$ was investigated from $\mathrm{H}_{2}$-Temperature-Programmed experiments. This analysis will allow us to gain more insight into the reducibility of cations located in B-sites. The consumption profiles vs. Temperature are reported in Fig. 4. They show that $\mathrm{LaFeO}_{3}$ is unreducible in the temperature range $100-700^{\circ} \mathrm{C}$. On the other hand, the reducibility of $\mathrm{Fe}^{3+}$ is improved on $\mathrm{La}_{0.7} \mathrm{FeO}_{3}$ with two broad signals appearing in the temperature ranges $300-400^{\circ} \mathrm{C}$ and $425-625^{\circ} \mathrm{C}$, which can be assigned to the two-step reduction of hematite in strong interaction with the perovskite structure [3]. A prominent reduction process occurs below $275^{\circ} \mathrm{C}$ after $\mathrm{Cu}$ and $\mathrm{Ca}$ substitutions tentatively ascribed to the main reduction of $\mathrm{Cu}^{2+}$ species to metallic species. Let us note that a shoulder clearly appears at $\sim 170^{\circ} \mathrm{C}$ on $\mathrm{La}_{0.7} \mathrm{Fe}_{0.8} \mathrm{Cu}_{0.2} \mathrm{O}_{3}$ which attenuates on Ca-doped samples. Such asymmetry could reflect the existence of different oxidic copper species, i.e. stabilized inside the perovskite lattice and/or segregated into more reducible oxidic species. This latter assumption seems in rather good agreement with XRD analysis showing distinctly the presence of a small fraction of $\mathrm{Cu}^{2+}$ stabilized as bulk $\mathrm{CuO}$. Clearly, the fraction of extra framework copper species diminishes at increasing calcium loading especially on stoichiometric composition, i.e. on $\mathrm{La}_{0.6} \mathrm{Ca}_{0.4} \mathrm{Fe}_{0.8} \mathrm{Cu}_{0.2} \mathrm{O}_{3}$. This suggests that the presence of higher density of defective sites on La-deficient perovskite, especially on $\mathrm{La}_{0.7} \mathrm{Fe}_{0.8} \mathrm{Cu}_{0.2} \mathrm{O}_{3}$, could favor the bulk diffusion of isolated oxidic copper species in octahedral position then segregating into $\mathrm{CuO}$. Calcium doping would partly prevent this process. 


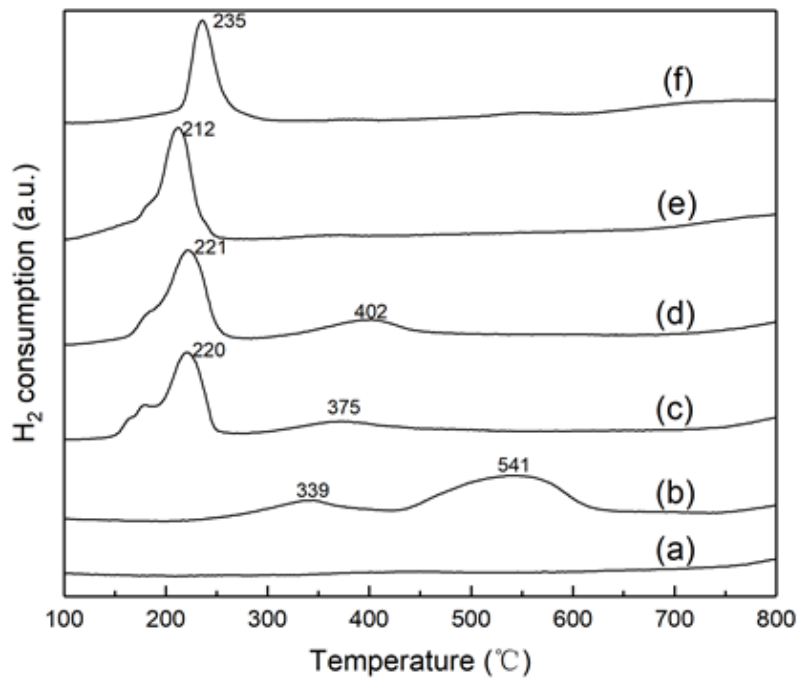

Fig. 4. Surface and bulk reducibility of stoichiometric and La-deficient $\mathrm{LaFeO}_{3}$ substituted by $\mathrm{Ca}$ and $\mathrm{Fe}$ : (a) $\mathrm{LaFeO}_{3}$; (b) $\mathrm{La}_{0.7} \mathrm{FeO}_{3} ; \quad$ (c) $\quad \mathrm{La}_{0.7} \mathrm{Fe}_{0.8} \mathrm{Cu}_{0.2} \mathrm{O}_{3} ; \quad$ (d) $\mathrm{La}_{0.6} \mathrm{Ca}_{0.1} \mathrm{Fe}_{0.8} \mathrm{Cu}_{0.2} \mathrm{O}_{3} ;$ (e) $\mathrm{La}_{0.6} \mathrm{Ca}_{0.2} \mathrm{Fe}_{0.8} \mathrm{Cu}_{0.2} \mathrm{O}_{3}$; (f) $\mathrm{La}_{0.6} \mathrm{Ca}_{0.4} \mathrm{Fe}_{0.8} \mathrm{Cu}_{0.2} \mathrm{O}_{3}$.

\subsection{Surface properties}

Surface composition was investigated by X-ray photoelectron spectroscopy. This technique allows the quantification of surface composition on a depth of 5-10 nm which could reflect the composition of the outermost layer for bulk catalysts. In addition, the oxidation state of the different elements can be discussed on the basis of the determination of Binding Energy values for characteristic core levels. In the particular case of perovskites, the $\mathrm{La} 3 \mathrm{~d}, \mathrm{Ca} 2 \mathrm{p}, \mathrm{Fe}$ $2 \mathrm{p}, \mathrm{Cu} 2 \mathrm{p}$ and $\mathrm{O} 1 \mathrm{~s}$ photopeaks have been investigated with B.E. values listed and compared in Table 3. As exemplified, they characterize essentially the stabilization of $\mathrm{La}^{3+}$ and $\mathrm{Ca}^{2+}$. The $\mathrm{Fe} 2 \mathrm{p}$ photopeak in Fig. 5 provides complementary information relative to the observation of a shake-up satellite structure near $719 \mathrm{eV}$ which reflects the predominance of $\mathrm{Fe}^{3+}$. B.E. values for the $\mathrm{Cu} 2 \mathrm{p}_{3 / 2}$ for reduced and oxidized copper species are currently reported near 932.6 and $934.2 \mathrm{eV}$ [16,17]. Accordingly, the $\mathrm{Cu} 2 \mathrm{p}$ core level near $934 \mathrm{eV}$, accompanied with the shake-up satellite structure in the range 939-950 eV characterize a greater stabilization of $\mathrm{Cu}^{2+}$. However, some peculiar spectral features are noticeable on $\mathrm{La}_{0.7} \mathrm{Fe}_{0.8} \mathrm{Cu}_{0.2} \mathrm{O}_{3}$ associated to a lower B.E. value and a significant attenuation of the shake-up structure which could reflect a reduction of the oxidation state of $\mathrm{Cu}^{2+}$ with a possible stabilization of $\mathrm{Cu}^{+}$species. The origin of such formation has been already discussed $[10,18]$ corresponding to more reducible $\mathrm{Cu}^{2+}$ than those stabilized in octahedral geometry of the perovskite. This could correspond to extra framework $\mathrm{Cu}^{2+}$ species as already characterized then their reduction to $\mathrm{Cu}^{+}$would proceed under irradiation during data acquisition. Let us note that the intensity of the peak satellite is progressively restored on Ca-doped samples which highlights their lower formation. The examination of the $\mathrm{Cu}$ LMM spectra 
complements XPS data to distinguish $\mathrm{Cu}(\mathrm{II}), \mathrm{Cu}(\mathrm{I})$ and $\mathrm{Cu}(0)$ species [19-21]. As seen in Fig. 6, the kinetic energy at $915.7 \mathrm{eV}$ on $\mathrm{La}_{0.7} \mathrm{Fe}_{0.8} \mathrm{Cu}_{0.2} \mathrm{O}_{3}$ agrees with the value earlier reported on $\mathrm{Cu}_{2} \mathrm{O}$ at $916.5 \mathrm{eV}$ and diverges from the current values ascribed to $\mathrm{CuO}$ and $\mathrm{Cu}^{0}$ respectively at 917.7 and $918.6 \mathrm{eV}$. Based on those data one can observed that the shift observed an Cadoped samples seems in relative good agreement with a preferential detection of $\mathrm{Cu}^{2+}$. The precise quantification of the relative amount of $\mathrm{Cu}(\mathrm{II})$ and $\mathrm{Cu}(\mathrm{I})$ species is a difficult task. However, a significant attenuation of the intensity Auger peak is discernible on Ca-doped samples which seems consistent with a significant lessening of the concentration of more reducible extra framework copper species especially on $\mathrm{La}_{0.6} \mathrm{Ca}_{0.4} \mathrm{Fe}_{0.8} \mathrm{Cu}_{0.2} \mathrm{O}_{3}$. In this latter case, the weak and broad peak would likely characterize less reducible isolated $\mathrm{Cu}^{2+}$ in octahedral position of the perovskite lattice stabilized at the surface.

The semi-quantitative analysis reveals significant changes on the surface composition. As shown in Table 3, usual surface La enrichment is noticeable on the parent stoichiometric $\mathrm{LaFeO}_{3}$ sample which is lowered on La-deficient samples even disappearing on $\mathrm{La}_{0.7} \mathrm{FeO}_{3}$ and calcium-doped samples. As a general trend, there is no significant deviation on the surface and bulk ratio $\mathrm{La} / \mathrm{Ca}$. On the other hand, significant fluctuations arise on the surface copper concentration, the highest surface concentration being observed on $\mathrm{La}_{0.7} \mathrm{Fe}_{0.8} \mathrm{Cu}_{0.2} \mathrm{O}_{3}$ then decreasing with a rise in $\mathrm{Ca}$ loading notably on the stoichiometric $\mathrm{La}_{0.6} \mathrm{Ca}_{0.4} \mathrm{Fe}_{0.8} \mathrm{Cu}_{0.2} \mathrm{O}_{3}$ sample. This tendency is consistent with the evolution observed on the Cu LMM Auger peak showing that the bulk diffusion of copper and subsequent surface enrichment is prevented on stoichiometric composition containing high amount of calcium.

(A)

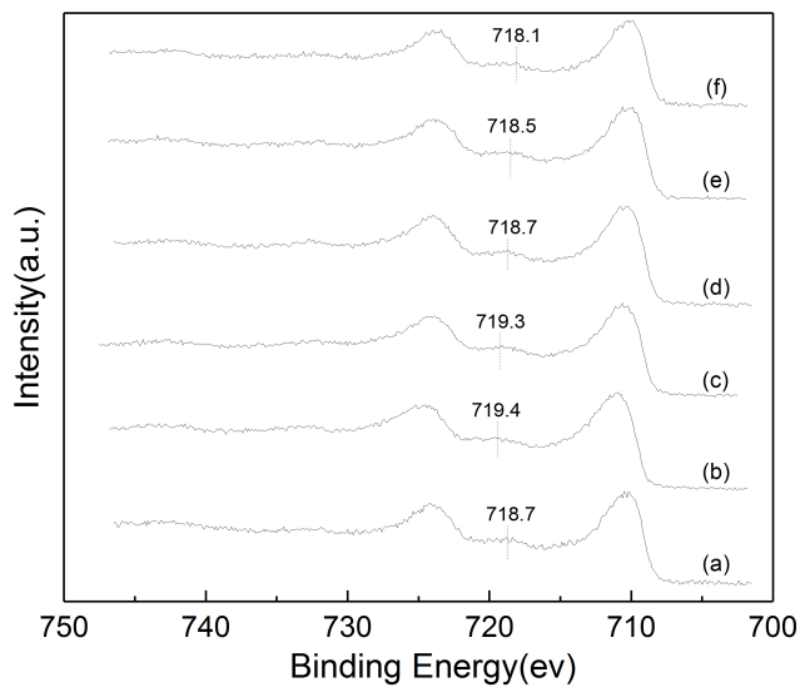

(B)

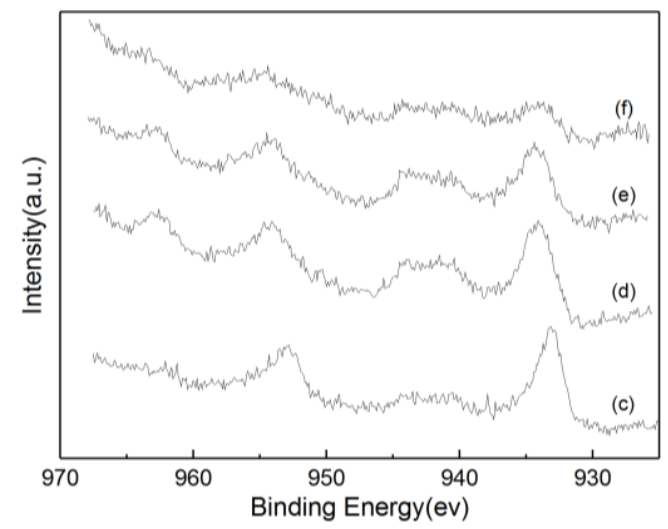

Fig. 5. Fe $2 p(A)$ and $\mathrm{Cu} 2 \mathrm{p}(\mathrm{B})$ XPS photopeak recorded on substituted $\mathrm{LaFeO}_{3}$ and $\mathrm{La}_{0.7} \mathrm{FeO}_{3}$ by calcium and copper. (a) $\mathrm{LaFeO}_{3}$; (b) $\mathrm{La}_{0.7} \mathrm{FeO}_{3}$; (c) $\mathrm{La}_{0.7} \mathrm{Fe}_{0.8} \mathrm{Cu}_{0.2} \mathrm{O}_{3} ; \quad$ (d) $\quad \mathrm{La}_{0.6} \mathrm{Ca}_{0.1} \mathrm{Fe} 0{ }_{.8} \mathrm{Cu}_{0.2} \mathrm{O}_{3} ; \quad$ (e) $\mathrm{La}_{0.6} \mathrm{Ca}_{0.2} \mathrm{Fe}_{0.8} \mathrm{Cu}_{0.2} \mathrm{O}_{3} ;$ (f) $\mathrm{La}_{0.6} \mathrm{Ca}_{0.4} \mathrm{Fe}_{0.8} \mathrm{Cu}_{0.2} \mathrm{O}_{3}$. 


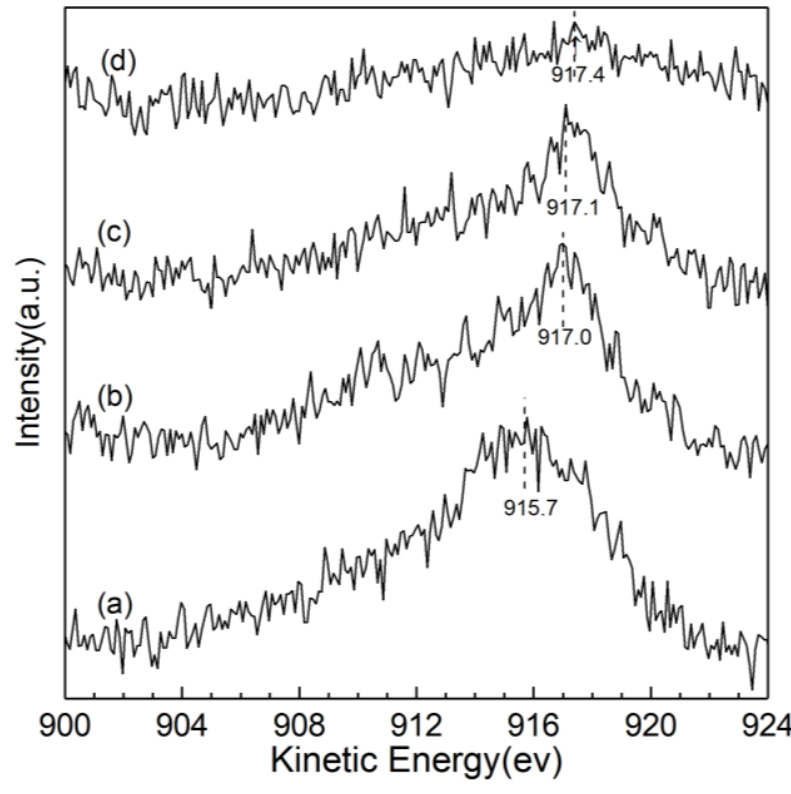

Fig. 6. $\mathrm{Cu}$ LMM Auger spectra on (a) $\mathrm{La}_{0.7} \mathrm{Fe}_{0.8} \mathrm{Cu}_{0.2} \mathrm{O}_{3} ; \quad$ (b) $\mathrm{La}_{0.6} \mathrm{Ca}_{0.1} \mathrm{Fe}_{0.8} \mathrm{Cu}_{0.2} \mathrm{O}_{3} ; \quad$ (c) $\mathrm{La}_{0.6} \mathrm{Ca}_{0.2} \mathrm{Fe}_{0.8} \mathrm{Cu}_{0.2} \mathrm{O}_{3} ;$ (d) $\mathrm{La}_{0.6} \mathrm{Ca}_{0.4} \mathrm{Fe}_{0.8} \mathrm{Cu}_{0.2} \mathrm{O}_{3}$.

Table 3. Surface analysis by XPS on calcined perovskite samples in air at $600^{\circ} \mathrm{C}$

\begin{tabular}{|c|c|c|c|c|c|c|c|c|}
\hline \multirow{2}{*}{ Catalyst } & \multicolumn{5}{|c|}{ Binding Energy $(\mathrm{eV})$} & \multicolumn{3}{|c|}{ Surface composition } \\
\hline & La 3d & $\mathrm{Ca} 2 \mathrm{p}$ & $\mathrm{Fe} 2 \mathrm{p}$ & $\mathrm{Cu} 2 \mathrm{p}$ & $\mathrm{O} 1 \mathrm{~s}$ & $\mathrm{La} / \mathrm{Ca}$ & $\mathrm{Cu} / \mathrm{Fe}$ & $\mathrm{A} / \mathrm{B}$ \\
\hline $\mathrm{LaFeO}_{3}$ & 833.8 & & 710.2 & & 529.1 & & & $1.34(1.02)$ \\
\hline $\mathrm{La}_{0.7} \mathrm{FeO}_{3}$ & 834.2 & & 710.9 & & 529.8 & & & $0.48(0.67)$ \\
\hline $\mathrm{La}_{0.7} \mathrm{Fe}_{0.8} \mathrm{Cu}_{0.2} \mathrm{O}_{3}$ & 833.7 & & 710.6 & 933.1 & 529.1 & & $0.18(0.26)$ & $0.52(0.68)$ \\
\hline $\mathrm{La}_{0.6} \mathrm{Ca}_{0.1} \mathrm{Fe}_{0.8} \mathrm{Cu}_{0.2} \mathrm{O}_{3}$ & 833.4 & 346.5 & 710.2 & 934.1 & 529.0 & $6.0(5.90)$ & $0.16(0.26)$ & $0.56(0.68)$ \\
\hline $\mathrm{La}_{0.6} \mathrm{Ca}_{0.2} \mathrm{Fe}_{0.8} \mathrm{Cu}_{0.2} \mathrm{O}_{3}$ & 833.3 & 346.2 & 709.9 & 934.4 & 529.0 & $3.1(3.00)$ & $0.15(0.26)$ & $0.76(0.79)$ \\
\hline $\mathrm{La}_{0.6} \mathrm{Ca}_{0.4} \mathrm{Fe}_{0.8} \mathrm{Cu}_{0.2} \mathrm{O}_{3}$ & 833.5 & 346.6 & 709.9 & 934.1 & 529.0 & $1.8(1.45)$ & $0.08(0.26)$ & $0.98(0.99)$ \\
\hline
\end{tabular}

\subsection{Catalytic performance vs physicochemical properties}

Fig. 7 reports the $\mathrm{CO}$ and propene conversion profiles vs. temperature recorded in stoichiometric conditions at the initial (STO1) and final stage (STO2) as described in the experimental section. The following sequence of activity can be derived from STO1 curves for $\mathrm{CO}$ oxidation : $\mathrm{LaFeO}_{3}<\mathrm{La}_{0.7} \mathrm{FeO}_{3}<\mathrm{La}_{0.6} \mathrm{Ca}_{0.4} \mathrm{Fe}_{0.8} \mathrm{Cu}_{0.2} \mathrm{O}_{3}<\mathrm{La}_{0.6} \mathrm{Ca}_{0.1} \mathrm{Fe}_{0.8} \mathrm{Cu}_{0.2} \mathrm{O}_{3} \cong$ $\mathrm{La}_{0.6} \mathrm{Ca}_{0.2} \mathrm{Fe}_{0.8} \mathrm{Cu}_{0.2} \mathrm{O}_{3}<\mathrm{La}_{0.7} \mathrm{Fe}_{0.8} \mathrm{Cu}_{0.2} \mathrm{O}_{3}$ whereas for propene oxidation the following ranking can be established : $\mathrm{La}_{0.6} \mathrm{Ca}_{0.4} \mathrm{Fe}_{0.8} \mathrm{Cu}_{0.2} \mathrm{O}_{3}<\mathrm{LaFeO}_{3}<\mathrm{La}_{0.7} \mathrm{FeO}_{3}<\mathrm{La}_{0.6} \mathrm{Ca}_{0.1} \mathrm{Fe}_{0.8} \mathrm{Cu}_{0.2} \mathrm{O}_{3}<$ $\mathrm{La}_{0.7} \mathrm{Fe}_{0.8} \mathrm{Cu}_{0.2} \mathrm{O}_{3}<\mathrm{La}_{0.6} \mathrm{Ca}_{0.2} \mathrm{Fe}_{0.8} \mathrm{Cu}_{0.2} \mathrm{O}_{3}$. As a general trend, both classifications underlined the superiority of La-deficient materials and, in a certain extent, calcium doping. It is worthwhile to note that the optimal composition for the oxidation of $\mathrm{CO}$ and propene differs, $\mathrm{La}_{0.7} \mathrm{Fe}_{0.8} \mathrm{Cu}_{0.2} \mathrm{O}_{3}$ being the most active for the former reaction whereas $\mathrm{La}_{0.6} \mathrm{Ca}_{0.2} \mathrm{Fe}_{0.8} \mathrm{Cu}_{0.2} \mathrm{O}_{3}$ exhibits the best performances for propene. A relative convergence is noticeable by examining their behavior in lean and rich conditions suggesting $\mathrm{La}_{0.6} \mathrm{Ca}_{0.2} \mathrm{Fe}_{0.8} \mathrm{Cu}_{0.2} \mathrm{O}_{3}$ as the 
most suited catalytic system (see Figs. 8 and 9). Important information is also provided by the comparison between STO1 and STO2 conversion curves highlighting opposite trends according the reaction considered. Interestingly, a rate enhancement is observed on $\mathrm{La}_{0.6} \mathrm{Ca}_{0.2} \mathrm{Fe}_{0.8} \mathrm{Cu}_{0.2} \mathrm{O}_{3}$ in propene oxidation whereas no significant deviation is noticeable for $\mathrm{CO}$ conversion. Conversely, slight changes occur mainly at low temperature on $\mathrm{La}_{0.7} \mathrm{Fe}_{0.8} \mathrm{Cu}_{0.2} \mathrm{O}_{3}$ for propene oxidation whereas a significant deactivation in $\mathrm{CO}$ conversion is observable. All those observations suggest that extensive of segregation of copper at the surface of $\mathrm{La}_{0.7} \mathrm{Fe}_{0.8} \mathrm{Cu}_{0.2} \mathrm{O}_{3}$ could partly explain the lower of performances recorded during STO2 experiments. Ca incorporation seems to have a beneficial effect especially on $\mathrm{La}_{0.6} \mathrm{Ca}_{0.2} \mathrm{Fe}_{0.8} \mathrm{Cu}_{0.2} \mathrm{O}_{3}$ which could correspond to a slower migration process and better dispersion of segregated copper species through a strengthening of the interaction with perovskite substrate.
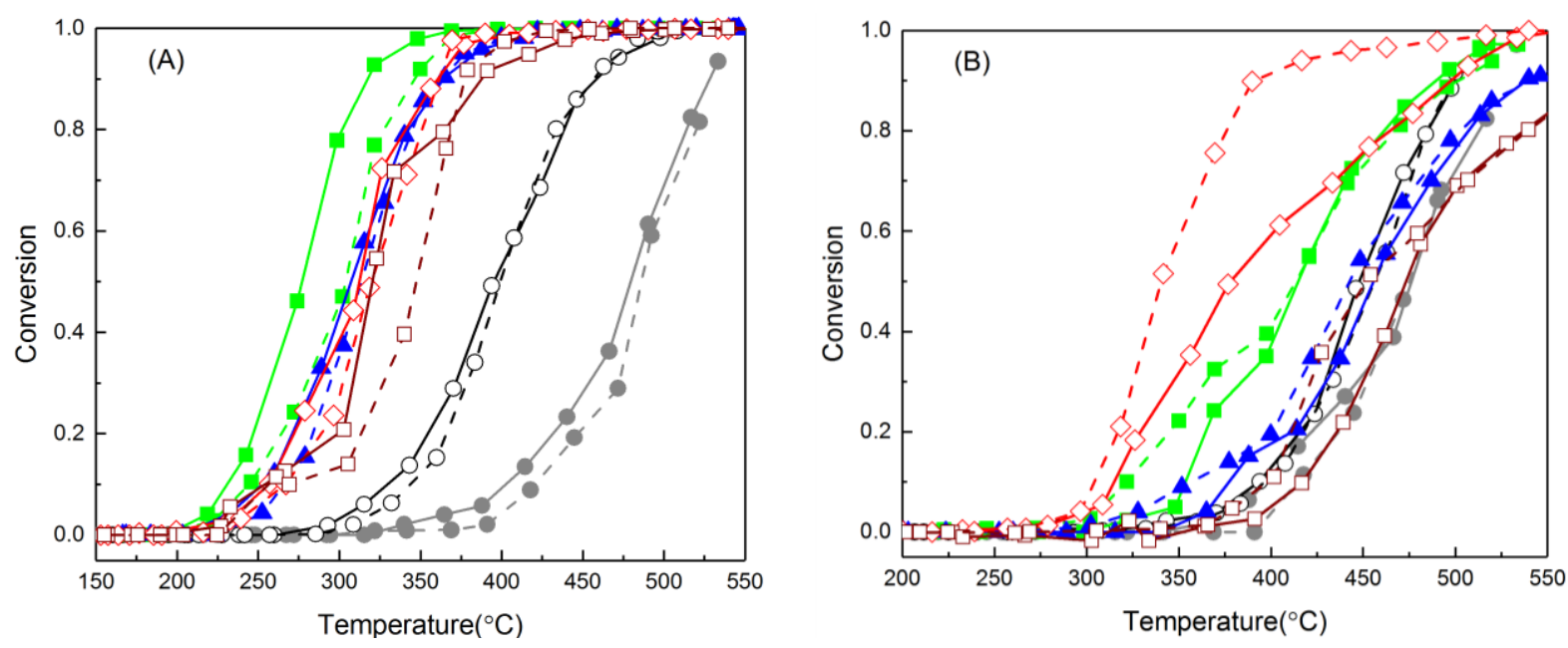

Fig. 7. TPR conversion profiles of $\mathrm{CO}(\mathrm{A})$ and propene (B) vs. temperature recorded in stoichiometric conditions on perovskites based samples : Full line (STO1), dotted line (STO2) : $\mathrm{LaFeO}_{3}(\bigcirc$ grey); $\mathrm{La}_{0.7} \mathrm{FeO}_{3} \quad(\mathrm{O} \quad$ black $) ; \quad \mathrm{La}_{0.7} \mathrm{Fe}_{0.8} \mathrm{Cu}_{0.2} \mathrm{O}_{3} \quad(\quad$ green $) ; \quad \mathrm{La}_{0.6} \mathrm{Ca}_{0.1} \mathrm{Fe}_{0.8} \mathrm{Cu}_{0.2} \mathrm{O}_{3} \quad$ ( $\boldsymbol{\Delta}$ blue $) ;$ $\mathrm{La}_{0.6} \mathrm{Ca}_{0.2} \mathrm{Fe}_{0.8} \mathrm{Cu}_{0.2} \mathrm{O}_{3}\left(\diamond \mathrm{r}\right.$ ed); $\mathrm{La}_{0.6} \mathrm{Ca}_{0.4} \mathrm{Fe}_{0.8} \mathrm{Cu}_{0.2} \mathrm{O}_{3}(\square$ brown).
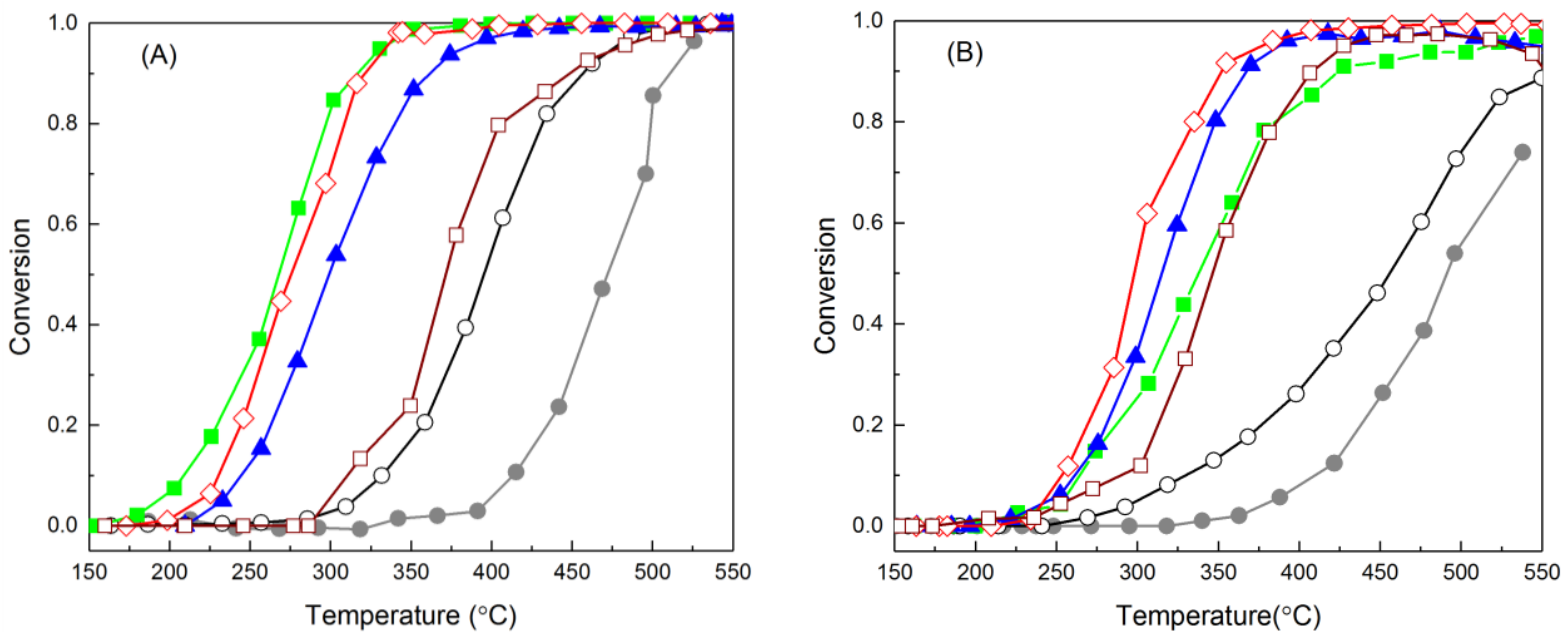
Fig. 8. TPR conversion profiles of $\mathrm{CO}$ in lean (A) and rich (B) conditions vs. temperature on perovskites based samples : $\mathrm{LaFeO}_{3}\left(\bigcirc\right.$ grey); $\mathrm{La}_{0.7} \mathrm{FeO}_{3}\left(\mathrm{O}\right.$ black); $\mathrm{La}_{0.7} \mathrm{Fe}_{0.8} \mathrm{Cu}_{0.2} \mathrm{O}_{3}$ ( $\square$ green); $\mathrm{La}_{0.6} \mathrm{Ca}_{0.1} \mathrm{Fe}_{0.8} \mathrm{Cu}_{0.2} \mathrm{O}_{3}(\boldsymbol{\Delta}$ blue $) ; \mathrm{La}_{0.6} \mathrm{Ca}_{0.2} \mathrm{Fe}_{0.8} \mathrm{Cu}_{0.2} \mathrm{O}_{3}(\diamond \mathrm{r}$ ed $) ; \mathrm{La}_{0.6} \mathrm{Ca}_{0.4} \mathrm{Fe}_{0.8} \mathrm{Cu}_{0.2} \mathrm{O}_{3}(\square$ brown).
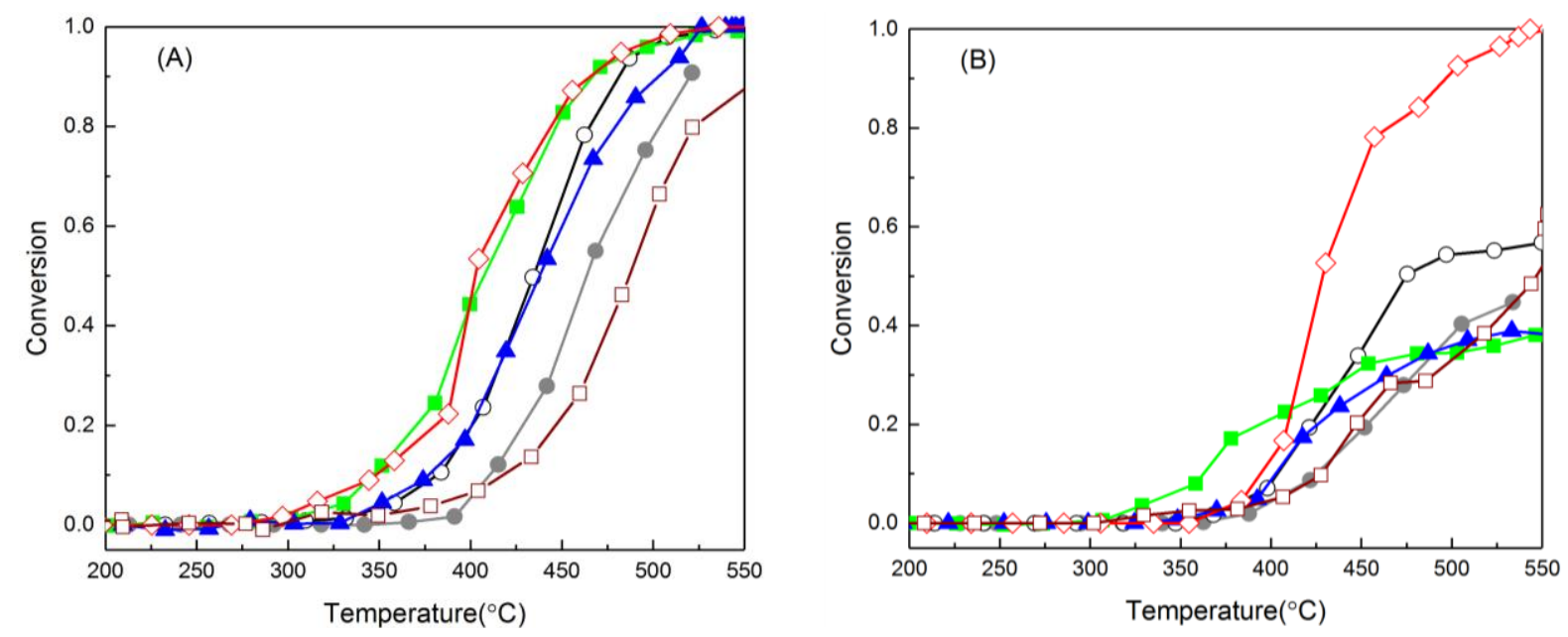

Fig. 9. TPR conversion profiles of propene in lean (A) and rich (B) conditions vs. temperature on perovskites based samples : $\mathrm{LaFeO}_{3}\left(\bigcirc\right.$ grey); $\mathrm{La}_{0.7} \mathrm{FeO}_{3}\left(\mathrm{O}\right.$ black); $\mathrm{La}_{0.7} \mathrm{Fe}_{0.8} \mathrm{Cu}_{0.2} \mathrm{O}_{3}$ ( $\square$ green); $\mathrm{La}_{0.6} \mathrm{Ca}_{0.1} \mathrm{Fe}_{0.8} \mathrm{Cu}_{0.2} \mathrm{O}_{3}(\Delta$ blue $) ; \mathrm{La}_{0.6} \mathrm{Ca}_{0.2} \mathrm{Fe}_{0.8} \mathrm{Cu}_{0.2} \mathrm{O}_{3}(\diamond \mathrm{r}$ ed $) ; \mathrm{La}_{0.6} \mathrm{Ca}_{0.4} \mathrm{Fe}_{0.8} \mathrm{Cu}_{0.2} \mathrm{O}_{3}(\square$ brown $)$.

\subsection{Catalytic vs. physicochemical properties}

This investigation shows that La-deficient $\mathrm{La}_{0.7} \mathrm{FeO}_{3}$ materials lead to higher catalytic performance than the $\mathrm{LaFeO}_{3}$ composition by promoting the surface enrichment of iron and large specific surface area. Subsequent substitutions of lanthanum $\left(\mathrm{La}^{3+}\right)$ by calcium $\left(\mathrm{Ca}^{2+}\right)$ and iron $\left(\mathrm{Fe}^{3+}\right)$ by copper $\left(\mathrm{Cu}^{2+}\right)$ lead to more complex surface chemistry as earlier discussed [10]. As shown in this study, the replacement of trivalent by divalent cations creates significant electronic imbalances. As a consequence, charge compensation can be provided by changes in the valence state of B-sites or oxygen vacancies. The creation of anionic vacancies is generally associated to a greater oxygen adsorption and in some extent a greater stabilization of supported nanoparticles of those materials. Both parameters can play an important role in determining the extent of reactivity and can reasonably explain the superiority of $\mathrm{La}_{0.6} \mathrm{Ca}_{0.2} \mathrm{Fe}_{0.8} \mathrm{Cu}_{0.2} \mathrm{O}_{3}$. Clearly, the segregation of $\mathrm{Fe}_{2} \mathrm{O}_{3}$ is characterized by $\mathrm{H}_{2}-$ TPR on $\mathrm{La}_{0.7} \mathrm{FeO}_{3}, \mathrm{La}_{0.7} \mathrm{Fe}_{0.8} \mathrm{Cu}_{0.2} \mathrm{O}_{3}$ and $\mathrm{La}_{0.6} \mathrm{Ca}_{0.1} \mathrm{Fe} 0{ }_{.8} \mathrm{Cu}_{0.2} \mathrm{O}_{3}$ as well as the stabilization of $\mathrm{Fe}^{4+}$ for $\mathrm{La}_{0.6} \mathrm{Ca}_{0.4} \mathrm{Fe}_{0.8} \mathrm{Cu}_{0.2} \mathrm{O}_{3}$ stoichiometric compositions as demonstrated by Mössbauer spectroscopic measurements. This technique also reveals significant structural constraints on Ca-doped samples with the formation of $\mathrm{Fe}^{3+}$ in distorted octahedral and tetrahedral centers. However, these changes cannot be easily correlated to the sequences of reactivity for $\mathrm{CO}$ and propene oxidation. 
Additional information, provided by XRD, XPS and $\mathrm{H}_{2}$-TPR experiments, is related to the characterization of extra lattice copper species on La-deficient perovskites more reducible than copper species stabilized in octahedral position in the perovskite lattice. XPS analysis clearly shows the highest $\mathrm{Cu} / \mathrm{Fe}$ atomic ratio on $\mathrm{La}_{0.7} \mathrm{Fe}_{0.8} \mathrm{Cu}_{0.2} \mathrm{O}_{3}$ corresponding to a sharp increase in intensity of Auger peak corresponding to $\mathrm{Cu}(\mathrm{I})$. As explained those species could come from the in situ reduction of those extra framework $\mathrm{Cu}$ (II) species. As exemplified, calcium doping induces a significant lessening of the concentration of extra framework copper species which quasi disappear on the stoichiometric composition $\mathrm{La}_{0.6} \mathrm{Ca}_{0.4} \mathrm{Fe}_{0.8} \mathrm{Cu}_{0.2} \mathrm{O}_{3}$. As a matter of fact, positive changes observed on the catalytic properties of $\mathrm{La}_{0.6} \mathrm{Ca}_{0.2} \mathrm{Fe}_{0.8} \mathrm{Cu}_{0.2} \mathrm{O}_{3}$ could be reasonably explained by an optimized Ca-doping jointly with La-deficiency. Both, likely induce the formation cubic $\mathrm{CuO}$ particles in stronger interaction than on $\mathrm{La}_{0.7} \mathrm{Fe}_{0.8} \mathrm{Cu}_{0.2} \mathrm{O}_{3}$, in agreement with previous observations [22]. The extent of dispersion of those oxidic copper species could depend on the flux of diffusion and surface re-dispersion related to the density of anionic vacancies and their stability. Based on this, the opposite changes observed on the STO1 and STO2 curves for CO and propene oxidation on $\mathrm{La}_{0.6} \mathrm{Ca}_{0.2} \mathrm{Fe}_{0.8} \mathrm{Cu}_{0.2} \mathrm{O}_{3}$ with respect to $\mathrm{La}_{0.7} \mathrm{Fe}_{0.8} \mathrm{Cu}_{0.2} \mathrm{O}_{3}$ would emphasize the stabilizing effect of calcium.

\section{Conclusion}

This study is a first step in the frame of the development of new TWC technologies coupled with particulate filters with the aim to develop thermally stable materials. The impact of A and B-substitution on the oxidative properties of parent stoichiometric and La-deficient $\mathrm{LaFeO}_{3}$ perovskites has been investigated. Particular attention was paid to $\mathrm{CO}$ and propene abatement showing that Ca-doping jointly with La-deficiency can lead to better performance monitoring the extent of copper for subsequent development as suitable substrate in Threeway Catalysis. $\mathrm{CO}$ and propene oxidation were investigated to probe their oxidative behavior. It was found that the activity cannot be related neither to the specific surface area nor to the nature of oxidic iron species but more likely to intra and extra lattice of copper species as well as related defective sites.

\section{Acknowledgement}

The authors acknowledge financial support by the EU-Partial-PGMs project (H2020-NMP686086). Chevreul Institute (FR 2638), Ministère de l'Enseignement Supérieur et de la 
Recherche, Région Nord - Pas de Calais and FEDER are acknowledged for supporting and funding partially this work.

\section{References}

1. Granger P (2008) Catal Sci Technol 7:5195-5211

2. Nishihata Y, Mizuki J, Akao T, Tanaka H, Uenishi M, Kimura M, Okamoto T, Hamada N. (2002) Nature 418:164-167.

3. Schoen A, Dujardin C, Dacquin JP, Granger P. (2015) Catal Today 258:543-548.

4. Wu Y, Dujardin C, Lancelot C, Dacquin JP, Parvulescu V, Cabié M, Henry CR, Neisius T, Granger P (2015) J Catal 328:236-247

5. Dacquin JP, Cabié M, Henry CR, Lancelot C, Dujardin C, Raouf SR, Granger P, (2010) J Catal 270:299-309

6. Dacquin JP, Lancelot C, Dujardin C, Granger P (2011) J. Phys Chem C 115:1911-1921

7. Wang L, Fang S, Feng N, Wan H, Guan G, (2016) Chem Eng J 293:68-74

8. López-Suárez FE, Bueno-López A, Illán-Gómez MJ, Trawczynski J (2014) Appl Catal A 485: 214-221

9. Emmerlich J, Linke BM, Music D, Schneider JM, (2014) Solid State Ionics 255:108-112

10. Schön A, Dacquin JP, Granger P, Dujardin C (2018) Appl Catal B 223:167-176

11. Wu Y, Ni X, Beaurain C, Dujardin C, Granger P (2012) Appl Catal B 125:149-157

12. Pushpa R, Daniel D (2013) Solid State Ionics 249-250:184-190

13. Glisenti A, Pacella M, Guiotto M, Natile MM, Canu P (2016) Appl Catal B 180:94-105

14. Pacella M, Garbujo A, Fabro J, Guiotto M, Xin Q, Natile NN, Canu P, Cool P, Glisenti A (2018) Appl Catal B 227:446-458

15. Pecchi G, Jiliberto MG, Buljean A, Delgado EJ (2011) Solid State Ionics 187:27-32

16. Lopez-Suarez FE, Parres-Esclapez S, Bueno-Lopez A, Illan-Gomez MJ, Ura B, Trawczynski J (2009) Appl Catal B 93:82-89

17. Zhang L, Nie Y, Hu C, Qu J (2012) Appl Catal B 125:418-424

18. Amano F, Tanaka T, Funabiki T (2004) J Mol Catal A 221:89-95

19. Biesinger MC, Lau LWM, Gerson AR, Smart RStC (2010) Appl Surf Sci 257:887-898.

20. Poulston S, Parlett PM, Stone P, Bowker M (1996), Surf. Interface Anal 24:811-820

21. Goh SW, Buckley AN, Lamb RN, Rosenberg RA, Moran D (2006) Geochim. Cosmochim. Acta 70:2210-2218

22. Garbujo A, Pacella M, Natile MM, Guiotto M, Fabro J, Canu P, Glisenti A (2017) Appl Catal A 544:94-107 